\title{
Clinical Use of a New Polymer in Complete Dentures Fabrication. II
}

\author{
DANA GABRIELA BOSINCEANU ${ }^{*}$, IOAN GABRIEL SANDU ${ }^{2,3}$, ELENA RALUCA BACIUㄴ, ZINOVIA SURLARII*, MARIA BOLAT ${ }^{1}$, \\ NORINA CONSUELA FORNA ${ }^{1}$ \\ ${ }^{1}$ Grigore T. Popa University of Medicine and Pharmacy lasi, 16 Universitatii Str., 700115, lasi, Romania \\ ${ }^{2}$ Gheorghe Asachi Technical University of Iasi, Faculty of Material Science and Engineering, 61A D. Mangeron Blvd., 700050, Iasi, \\ Romania \\ ${ }^{3}$ Romanian Inventors Forum, 3 Sf. Petru Movila, Str. BI. L11, Sc. III, Et. 3, Ap.3, 700089, Iasi, Romania

\begin{abstract}
In total edentulous treatment can be used a variety of means capable to reconstruct through artificial prosthetic devices the edentulous dental arches, in an individualized manner depending on the clinical situation, objectives and criteria for treatment. The present study was intended to evaluate the effectiveness of general treatment with vitamin B12 and the effectiveness of local treatment, achieved through complete dentures and to emphasize the much easier and cheaper way to do the same treatment over the same time period.
\end{abstract}

Keywords: cyanocobalamin, denture wearers, elderly, acrylic polymer, health care

Dentistry has seen a remarkable development in recent decades and has become increasingly important in health care practice. Continuous improvement of clinical and research methods with modern and advanced equipment has considerably broadened the rigorous scientific basis for dental medicine. Acrylic resins were firstintroduced to dentistry as denture base materials in 1937 [1-4]. They had revolutionized denture base materials to the extent that in 1946, 98\% of all denture bases were fabricated from polymethylmethacrylate (PMMA) or copolymers. Heat cured polymethylmethacrylate (PMMA) resin is the most widely used material for the construction of removable prostheses due to its superior physical and chemical characteristics, ease of processing and reasonable cost [5-9]. The use of polymeric resins has since reached appliance in multiple medical fields, especiallyin technical design of medical devices [10, 11]. Research focused on denture base resins led to evolution of many advances such as vinyl resins, polystyrene, epoxy resins, polycarbonates, polyurethanes, and cyanoacrylates. Despite so many advances, PMMAs remain the material of choice for removable complete and partial edentulous prostheses. Low cost, relative ease of use, and reliance on simple processing equipment favored their popularity over other materials. However there are a few limiting properties, most importantly is the release of residual methyl methacrylate monomer (MMA) which affects the dimensional stability, the adherence of oral bacteria such as Candida albicans to the resin and the prolonged chair side appointments required for the fabrication of the prostheses. Such limitations have led general practitioners to shy away from treating edentulous patients [12-21]. The presence of residual monomer in denture base resins adversely affects both the mechanical properties and the biocompatibility of these resins as leaching out of the monomer gives rise to allergic reactions with symptoms such as burning sensations, stomatitis, edema and ulceration of the oral mucosa [22-24]. By comparing the tinctorial behaviour of the acrylic supports in the oral cavity in other mediums [25-28] and of colour differences can also highlight the impact of using vitamin B12.

Because cyanocobalamin deficiency is commonly treated parenterally, the present study aims to compare the effectiveness of general treatment with vitamin B12 with the effectiveness of local treatment by complete

*email: danab1978@yahoo.com; zinamaseluta@yahoo.com dentures for a group of edentulous patients treated in the Faculty of Dental Medicine lasi. The polymer used is crosslinked acrylate with cyanocobalamin as template $[14,24]$.

\section{Experimental part \\ Materials and methods}

The present paper is a continuation of a previous study published [14] conducted on the patients aged between 55-64. The part II is a study conducted on the group age of 65-74 composed of 29 patients, 10 men and 19 women. They came from an initial group of 252 patients with complete edentulous arches and all patients were informed and gave their agreement regarding the study. The exclusion criteria were represented by patients with mental illnesses. Also, consideration was given to the criteria of gastrointestinal diseases which have as main manifestation the malabsorption that could influence the results of the general treatment and patients with such general antecedents were excluded. Sangiuolo class III was also an exclusion criteria due to the lack of dentures stability in order not to influence local treatment by the inability of wearing the dentures or by adding adhesives to the mucous faces of the dentures thus stopping the release of the whole vitamin B12.

To this group of patients, a new selection was performed based on the blood count that provided important data on the type and number of blood cells of the homocysteine and methyl malonic acid test, the level of these substances increasing with the decrease in vitamin B12. Patients with vitamin B12 deficiency anemia were selected. These were 7 men and 10 women in the 65-74 age group.

The treatment schedule applied for parenteral treatment was as follows: $1 \mathrm{mg}$ im on days $3^{\text {rd }}, 7^{\text {th }}, 10^{\text {th }}, 14^{\text {th }}, 21^{\text {st }}, 30^{\text {th }}$, $60^{\text {th }}, 90^{\text {th }}$ - locally via complete dentures, in which the template polymerization method described in the previous paper was used, the template being vitamin B12. Patients were advised for treatment to keep the dentures in a glass of water and vitamin B12 for 8 hours a day in order to be able to collect $2 \mathrm{mg}$ daily for 120 days.

\section{Results and discussions}

Based on the statistical analysis of data obtained for the 65-74 age group, mean values for vitamin B12 of $157.87 \mathrm{~g} /$ $\mathrm{mL}, 340.12 \mathrm{nmol} / \mathrm{L}$ methylmalonic acid and $15.28 \mu \mathrm{mol} / \mathrm{L}$ 


\begin{tabular}{|l|c|c|c|c|c|c|}
\hline & $\begin{array}{c}\text { B12 } \\
\text { initial }\end{array}$ & $\begin{array}{c}\text { Methylmalonic } \\
\text { acid initial }\end{array}$ & $\begin{array}{c}\text { Homocysteine } \\
\text { Initial }\end{array}$ & $\begin{array}{c}\text { B12 } \\
\text { after 120 } \\
\text { days }\end{array}$ & $\begin{array}{c}\text { Methylmalonic } \\
\text { acid after 120 } \\
\text { days }\end{array}$ & $\begin{array}{c}\text { Homocysteine } \\
\text { after 120 days }\end{array}$ \\
\hline N Valid & 8 & 8 & 8 & 8 & 8 & 8 \\
\hline Misging & 0 & 0 & 0 & 0 & 0 & 0 \\
\hline Mean & 157.8750 & 340.1250 & $\underline{15.2875}$ & 496.6250 & -313.3750 & 8.6375 \\
\hline $\begin{array}{l}\text { Std. Error of Mean } \\
\text { Std. Deviation }\end{array}$ & 4.68446 & 9.97396 & -37864 & 15.72752 & 26.33841 & -24271 \\
\hline
\end{tabular}

Table 1

STATISTIC VALUES IN

65-74 YEARS OLD

GROUP FOR

PARENTERAL

TREATMENT

\begin{tabular}{|l|l|r|r|r|}
\hline & & $\mathbf{N}$ & \multicolumn{1}{|c|}{$\begin{array}{c}\text { Mean } \\
\text { Rank }\end{array}$} & $\begin{array}{c}\text { Sum of } \\
\text { Ranks }\end{array}$ \\
\hline $\begin{array}{l}\text { B12, after,120 } \\
\text { days - B12 initial }\end{array}$ & $\begin{array}{l}\text { Negative } \\
\text { Ranks }\end{array}$ & 0 & .00 & .00 \\
\cline { 2 - 5 } & $\begin{array}{l}\text { Positive } \\
\text { Ranks }\end{array}$ & 8 & 4.50 & 36.00 \\
\cline { 2 - 5 } & Ties & 0 & & \\
\cline { 2 - 5 } & Total & 8 & & \\
\hline \multirow{4}{*}{$\begin{array}{l}\text { methylmalonic } \\
\text { methylmalonic } \\
\text { initial }\end{array}$} & $\begin{array}{l}\text { Negative } \\
\text { Ranks }\end{array}$ & 1 & 1.00 & 1.00 \\
\cline { 2 - 5 } & $\begin{array}{l}\text { Positive } \\
\text { Ranks }\end{array}$ & 0 & .00 & \\
\cline { 2 - 5 } & Ties & 7 & & .00 \\
\cline { 2 - 5 } & Total & 8 & & \\
\hline \multirow{2}{*}{$\begin{array}{l}\text { Homocysteine 120 } \\
\text { days initial }\end{array}$} & $\begin{array}{l}\text { Negative } \\
\text { Romocysteine }\end{array}$ & 8 & 4.50 & \\
\cline { 2 - 5 } & $\begin{array}{l}\text { Positive } \\
\text { Ranks }\end{array}$ & 0 & .00 & \\
\cline { 2 - 5 } & Ties & 0 & & .00 \\
\cline { 2 - 5 } & Total & 8 & & \\
\hline
\end{tabular}

Table 2

TEST WILCOXON FOR PARENTERAL TREATMENT

\begin{tabular}{|l|r|r|r|}
\hline & $\begin{array}{c}\text { B12 after 120 } \\
\text { days - B12 initial }\end{array}$ & $\begin{array}{c}\text { Methylmalonic after } \\
\mathbf{1 2 0} \text { days } \\
\text { methylmalonicinitial }\end{array}$ & $\begin{array}{c}\text { Homocysteine 120 days - } \\
\text { initial Homocysteine }\end{array}$ \\
\hline $\begin{array}{l}\text { Z } \\
\text { Asymp. Sig. } \\
\text { (2-tailed) }\end{array}$ & $-2.521^{2}$ & $-1.000^{\circ}$ & $-2.524^{\circ}$ \\
\hline
\end{tabular}

Table 3

TEST STATISTICS

\footnotetext{
a. Based on negative ranks.

b. Based on positive ranks.
}

\begin{tabular}{|c|c|c|c|c|c|c|c|}
\hline & $\begin{array}{c}\mathrm{Bl2} \\
\text { initial }\end{array}$ & $\begin{array}{c}\text { Methylmalonic } \\
\text { Acid }\end{array}$ & homocysteine & B12 120 days & $\begin{array}{c}\text { Methylmalonic Acid } 120 \\
\text { Days }\end{array}$ & $\begin{array}{c}\text { Homocysteine } 120 \\
\text { days }\end{array}$ & \multirow{6}{*}{$\begin{array}{c}\text { Table } 4 \\
\text { STATISTIC VALUES } \\
\text { IN 55-64 YEARS } \\
\text { OLD GROUP FOR } \\
\text { LOCAL } \\
\text { TREATMENT }\end{array}$} \\
\hline N Valid & 9 & 9 & 9 & 9 & 9 & 9 & \\
\hline Missing & 0 & 0 & 0 & 0 & 0 & 0 & \\
\hline Mean & $\underline{154.7778}$ & 340.8889 & $\underline{15.5000}$ & $\underline{504.0000}$ & 247.3333 & $\underline{9.6778}$ & \\
\hline $\begin{array}{l}\text { Std. Error } \\
\text { of Mean }\end{array}$ & 4.07151 & 6.90098 & .29250 & 18.91501 & 38.98825 & .26235 & \\
\hline $\begin{array}{l}\text { Std. } \\
\text { Deviation }\end{array}$ & 12.21452 & 20.70293 & .87750 & 56.74504 & 116.96474 & .78705 & \\
\hline
\end{tabular}

homocysteine were obtained prior to local supply and $496.62 \mathrm{~g} / \mathrm{mL}, 313.37 \mathrm{nmol} / \mathrm{L}$ and $8.63 \mu \mathrm{mol} / \mathrm{L}$ after the treatment, as summarized in the table 1 above.

There is an increase in B12 level and decrease in the level of methylmalonic acid and homocysteine. We are interested in whether these differences are statistically significant and the results are shown in tables 2 and 3 above.

According to the Wilcoxon test, there are statistically significant differences between the final scores of the two values as follows: Initial B12 - B12 after 120 days (Wilcoxon: $\mathrm{N}=5, \mathrm{z}=2.521$, two-tailed $=0.012$ ssstatistically significant). Initial Methylmalonic Acid Methylmalonic Acid 120 Days (Wilcoxon: $\mathrm{N}=5, \mathrm{z}=1.000$, two-tailed $=0.317 \mathrm{ss})$. Initial homocysteine Homocysteine 120 days (Wilcoxon: $N=5, z=2.524$, twotailed $=0.012 \mathrm{ss}$ ).
For local treatment with dentures the results are shown in table 4.

There is an increase in B12 levels and decreases in the levels of methylmalonic acid and homocysteine. We are interested in whether these differences are statistically significant that is why we will applied the Wilcoxon test, the nonparametric equivalent of the $t$ test and in tables 5 and 6 we have the results.

According to the Wilcoxon test, there are statistically significant differences between the final scores of the two groups as follows:

-Initial B12 - B12 after 120 days (Wilcoxon: $N=5, z=$ 2.668, two-tailed $=0.008$ ss - statistically significant).

-Initial Methylmalonic Acid - Methylmalonic Acid 120

Days (Wilcoxon: $\mathrm{N}=5, \mathrm{z}=1.826$, two-tailed $=0.068 \mathrm{ss}$ ).

-Initial homocysteine - Homocysteine 120 days (Wilcoxon: $\mathrm{N}=5, \mathrm{z}=2.668$, two-tailed $=0.008 \mathrm{ss}$ ). 


\begin{tabular}{|l|r|r|r|}
\hline & $\begin{array}{c}\text { B12 after 120 } \\
\text { days - B12 } \\
\text { initial }\end{array}$ & $\begin{array}{c}\text { methylmalonic after } \\
\text { 120 days methylmalonic } \\
\text { initial }\end{array}$ & $\begin{array}{r}\text { Homocysteine 120 days - } \\
\text { initial Homocysteine }\end{array}$ \\
\hline Z & $-2.668^{\mathrm{a}}$ & $-1.826^{\mathrm{b}}$ & $-2.668^{\mathrm{b}}$ \\
\hline $\begin{array}{l}\text { Asymp. Sig. } \\
\text { (2-tailed) }\end{array}$ & $\underline{.008}$ & $\underline{.068}$ & $\underline{.008}$ \\
\hline
\end{tabular}

Table 5

TEST WILCOXON FOR LOCAL TREATMENT

$\begin{array}{ll}\text { a. } & \text { Based on negative ranks. } \\ \text { b. } & \text { Based on positive ranks. }\end{array}$

\begin{tabular}{|c|c|c|c|c|}
\hline & & $\mathbf{N}$ & Mean Rank & Sum of Ranks \\
\hline \multirow{4}{*}{$\begin{array}{l}\text { B12afterl20days - } \\
\text { B12 initial }\end{array}$} & Negative Ranks & 0 & .00 & .00 \\
\hline & Positive Ranks & 9 & 5.00 & 45.00 \\
\hline & Ties & 0 & & \\
\hline & Total & 9 & & \\
\hline \multirow{4}{*}{$\begin{array}{l}\text { Methylmalonic } \\
\text { afterl20days } \\
\text { methylmalonic initial } \\
\text { Acmetilmaloni initial }\end{array}$} & Negative Ranks & 4 & 2.50 & 10.00 \\
\hline & Positive Ranks & 0 & .00 & .00 \\
\hline & Ties & 5 & & \\
\hline & Total & 9 & & \\
\hline \multirow{4}{*}{$\begin{array}{l}\text { Homocysteine } \\
\text { afterl20 days } \\
\text { Homocysteine initial }\end{array}$} & Negative Ranks & 9 & 5.00 & 45.00 \\
\hline & Positive Ranks & 0 & .00 & .00 \\
\hline & Ties & 0 & & \\
\hline & Total & 9 & & \\
\hline
\end{tabular}

Table 6

TEST STATISTICS
Although popular for various reasons, PMMA exhibited dimensional changes which were found to be attributed to processing technique [14]. Over the years, many advances took place in the processing techniques of resins such as compression molding, injection molding, and fluid resin techniques. Template polymerization was designed to optimize mass polymerization to produce high crosslinked polymers having the characteristics of thermally, mechanically and chemically resistant materials [12]. It has been observed that the polymers obtained in the presence of templates have a selective memory, preferentially retaining products with a template-like structure, in our case retaining a higher amount of vitamin B12 than that used in the synthesis [20, 22].

As this study is an in vivo study that was conducted on completely edentulous patients with dentures, there were variations in the area of denture bearing surface and residual ridge forms. These factors may alter the amount of resin used for each denture, thereby affecting amount of template in each denture. It was minimized by considering size of the ridge during sample selection. The study should be done on larger sample of edentulous patients to conclude the accuracy of results. Future research as a continuation of the present study needs to be done to evaluate interferences in vivo in patient's oral cavity.

\section{Conclusions}

The analyzes performed in the study group focused on the serum values of cyanocobalamin, methylmalonic acid and homocysteine, resulting in increased levels of cyanocobalamin and lower the values of the other two elements in order for the treatment to be effective.

The treatment schedule used has shown to be applicable with viable results in the treatment of cyanocobalamin deficiency, both parenterally and local, using acrylate together polymerized with vitamin B12 as template.

The results of the statistical studies performed on the age group of patients have been shown to be significantly different in terms of obtaining results both from parenteral and local treatment, the latter being superior to the parenteral and also much easier to apply.

\section{References}

1. LOVELL, L.G., BERCHTOLD, K.A., ELLIOT, J.E., LU, H., BOWMAN, C.N., Polymers for Advanced Technologies, 12, 2001, p. 335.

2. BOSINCEANU, D.N., BOSINCEANU, D.G., BOLAT, M., BACIU, R., FORNA, N.C., Rom. J. Oral Rehab., 8, no. 1, 2016, p.7.

3. IOSIF, L., AMZA, O.E., PREOTEASA, E., AMZA G., PREOTEASA, C.T., DUMITRASCU, C., Mat. Plast., 48, no. 1, 2011, p.104.

4. BOSINCEANU, D.N., SANDU, I.G., BOSINCEANU, D.G., FORNA, N.C., Rev. Chim. (Bucharest), 65, no. 4, 2014, p. 466.

5. EARAR, K., BICA, C., CERGHIZAN, D., ILIE, M., Mat. Plast., 53, no. 3, 2016, p. 512.

6. EARAR, K., CERGHIZAN, D., SANDU, A.V., MATEI, M.N., LEATA, R., SANDU, I.G., BEJ INARIU, C., COMAN, M., Mat. Plast., 52, no. 4, 2015, p. 487.

7. EARAR, K., MATEI, M.N., SANDU, A.V., HRISTIAN, L., BEJ INARIU, C., SANDU, I.G., Mat. Plast., 52, no. 1, 2015, p. 98.

8. DIACONU POPA, D., VITALARIU, A., TATARCIUC, M., MUNTEANU,

F., Rev. Chim. (Bucharest), 67, no. 8, 2016, p. 1571.

9. SAVIN, C., PETCU, A., GAVRILA, L., MARTU-STEFANACHE, M.A., BALAN, A., International J ournal of Medical Dentistry, 20, no. 3, 2016, p. 171.

10. BALAN, G.G., PAVEL, L., SANDU, A.V., STEFANESCU, G., TRIFAN, A.V., Mat. Plast., 53, no.4, 2016, p. 791.

11. BALAN, G.G., ROSCA, I., URSU, E.L., DOROFTEI, F., BOSTANARU, A.C., HNATIUC, E., NASTASA, V., SANDRU, V., STEFANESCU, G., TRIFAN, A., MARES, M., Infection and drug resistance, 11, 2018, p.727.

12. GAVRILA, L., MAXIM, A., BALAN, A., STOLERIU, S., SANDU, A.V., SERBAN, V., SAVIN, C., Rev. Chim. (Bucharest), 66, no. 8, 2015, p. 1159.

13. BORTUN, C.M., CERNESCU, A., ARDELEAN, L., Mat. Plast., 49, no. 1,2012

14. BOSINCEANU, D.G., SANDU, I.G., BOSINCEANU, D.N., MARTU, I., SURLARI, Z., FORNA, N.C. Mat. Plast., 55, no. 3, 2018, p. 423.

15. MARTU, I., BOSINCEANU, D.G., FORNA, N.C., VITALARIU, M.A., LUCHIAN, I., BOSINCEANU, D.N., Rom. J. Oral Rehab., 9, no. 2, 2017, p. 60. 
16. SOLOMON, S.M., STOLERIU, S., FORNA, D.A., TAMPU, D., STEFANACHE, M.A.M., URSARESCU, I.G., MARTU, S., Mat. Plast., 53, no. 2, 2016, p. 304.

17. MARTU, S., NICOLAICIUC, O., SOLOMON, S., Rev Chim (Bucharest), 68, no. 5, 2017, p. 1946.

18. SOLOMON, S.M., PASARIN, L., URSARESCU, I., MARTU, I., BOGDAN, M., NICOLAICIUC, O., IOANID, N., MARTU , S., Int. J. Exp. Med., 9, no. 2, 2016, p. 4411.

19. MARTU, I., GORIUC, A., MARTU, M.A., VATA, I., BACIU, R., MOCANU, R., SURDU, A.E., POPA, C., LUCHIAN, I., Rev. Chim. (Bucharest), 68, no. 10, 2018, p. 2407.

20. SANDU, A.V., CODDET, C., BEJ INARIU, C., Rev. Chim. (Bucharest), 64, 2012, p. 401.

21. OGODESCU, A.S., MORVAY, A.A., BALAN, A., GAVRILA, L., PETCU, A., SAVIN, C., Mat. Plast., 54, no. 1, 2017, p. 116.

22. HRIB, C.G., SANDU, I., EARAR, K., BIRSA, L.M., Rev. Chim. (Bucharest), 65, no. 12, 2014, p. 1453.
23. FORNA, D.A., FORNA, N.C., EARAR, K., POPESCU, E., Mat. Plast., 54, no. 2, 2017, p. 312.

24. BOLAT, M., BOSINCEANU, D.N., BACIU, E.R., FORNA AGOP, D., BOSINCEANU, D.G., FORNA, N.C., Rom. J. Oral Rehab., 9, no. 4, 2017, p.93.

25. TOTU, E.E., CRISTACHE, C.M., Rev. Chim. (Bucharest), 68, no. 9, 2017, p. 2102.

26. MANEA, L.R., BERTEA, A., NECHITA, E., POPESCU, C.V., SANDU, I., Rev. Chim. (Bucharest), 67, no. 8, 2016, p. 1607.

27. MANEA, L.R., BERTEA, A., NECHITA, E., POPESCU, C.V., SANDU, I., Rev. Chim. (Bucharest), 67, no. 7, 2016, p. 1284.

28. POPESCU, V., SANDU, I.C.A., POPESCU, G., Rev. Chim. (Bucharest), 67, no. 1, 2016, p. 74.

$\overline{\text { Manuscript received: } 10.10 .2018}$ 